\title{
Diagnostic difficulties delaying treatment in a patient with fibrous dysplasia of the right femur
}

\author{
Mohammad Al-Ashqar, ${ }^{1}$ Sarah Gowlett, ${ }^{2}$ Ian Baxter ${ }^{1}$
}

${ }^{1}$ Department of Orthopaedics, Northern General Hospital, Sheffield, South Yorkshire, UK ${ }^{2}$ Department of Radiology, Northern General Hospital, Sheffield, South Yorkshire, UK

\section{Correspondence to}

Dr Mohammad Al-Ashqar, m.a.al-ashqar@doctors.org.uk

\section{DESCRIPTION}

A 47-year-old man was admitted to a hospital after developing acute severe right hip pain upon standing up from a kneeling position. He was unable to bear weight and had no history of recent trauma. $\mathrm{X}$-rays showed suspected right neck of femur fracture in an abnormal femur.

He was noted to have a history of 6 months of right thigh pains, causing occasional antalgic gait. He had been investigated prior to his acute admission with plain X-ray radiographs, MRI and dynamic isotope scan. His X-rays and MRI were suggestive of either chronic osteomyelitis, fibrous dysplasia or a benign tumour (figures 1 and 2). The T2-weighted MRI showed a breach in the cortex of his femur, suggesting a bone infection rather than dysplasia (figure 3). ${ }^{1}$ His isotope bone scan showed increased uptake localised to his right proximal femur-where his pains were-suggestive of an infection or tumour (figure 4).

He was deemed to have a pathological fracture; however, surgical intervention was delayed until a definitive diagnosis was made. If he did indeed have an infection, then any prosthetic implants or open reduction and internal fixation would be contraindicated. His pain was controlled with traction, and he underwent a right proximal femur biopsy and hip aspiration to confirm his diagnosis. $\mathrm{He}$ remained as an inpatient for 10 days for analgesia

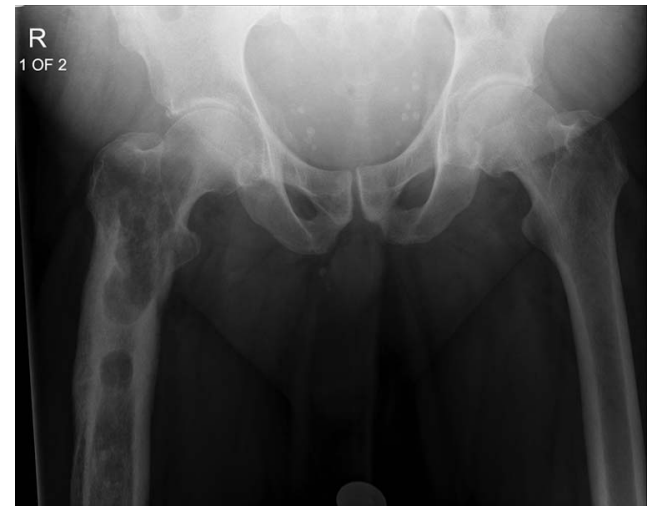

Figure 1 Antero-posterior pelvis $\mathrm{X}$-ray before acute admission showing fibrous dysplasia of the right proximal femur.

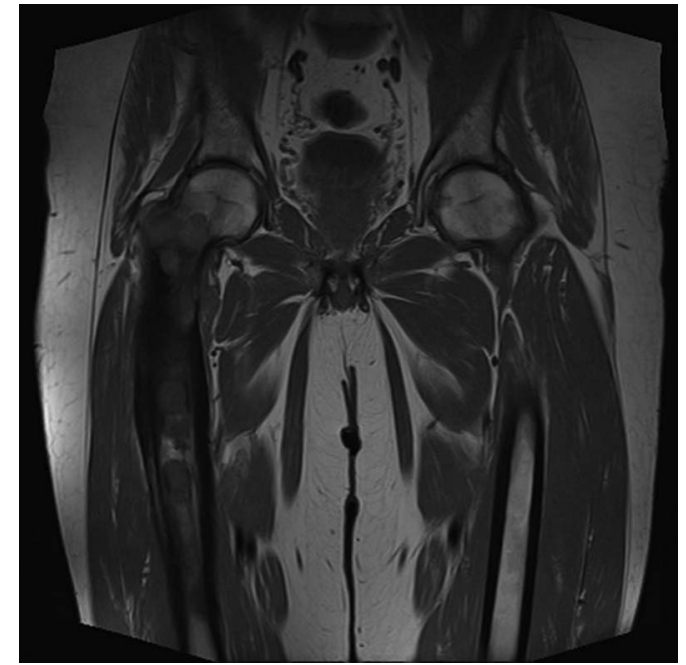

Figure 2 Antero-posterior pelvis MRI before acute admission showing fibrous dysplasia of the right proximal femur.

and traction while awaiting histology and microbiology results.

Ultimately microbiology tests were negative for infection and histological analysis excluded tumour and confirmed a diagnosis of fibrous dysplasia.

He was therefore treated with a long-stem total hip replacement to good effect.

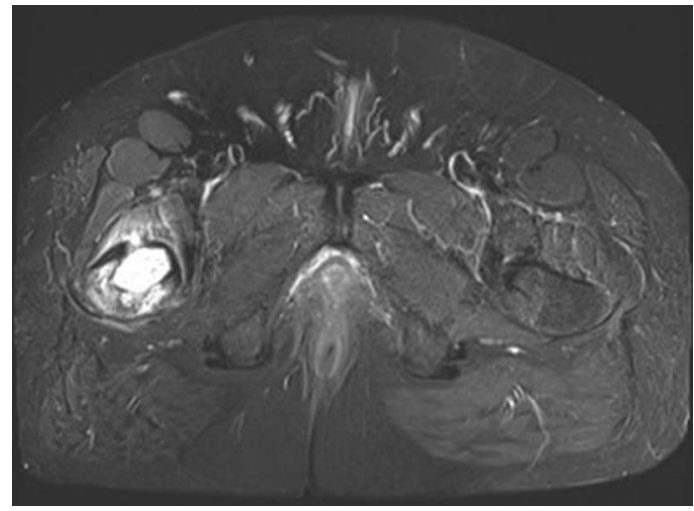

Figure 3 Axial MRI (T2) of proximal femurs showing suspected fluid breaching cortex of right femur. 


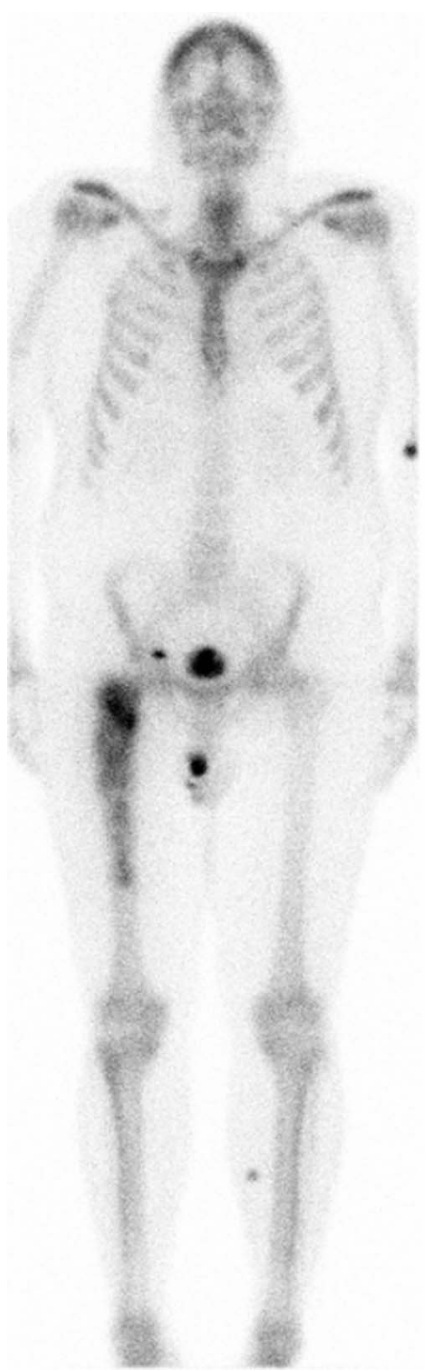

\section{Learning points}

- Fibrous dysplasia should be considered as a differential diagnosis in pathological fractures.

- Radiological features of fibrous dysplasia may be confused with malignancy or infection.

- Fibrous dysplasia rarely breaches the cortex of the bone, unless due to a pathological fracture.

- 'Hot' areas on dynamic bone scan are suggestive of infection or tumour. Fibrous dysplasia can also be 'hot' on bone scan depending on cellularity.

- Establishing diagnosis is vital before the definitive treatment of a pathological fracture.

Competing interests None.

Patient consent Obtained.

Provenance and peer review Not commissioned; externally peer reviewed.

\section{REFERENCE}

1 Dahnert W. Radiology review manual. 3rd edn. Philadelphia: Lippincott Williams and Wilkins, 1996.

Figure 4 Isotope bone scan showing increased uptake ('hot' area) in right proximal femur.

Copyright 2013 BMJ Publishing Group. All rights reserved. For permission to reuse any of this content visit

http://group.bmj.com/group/rights-licensing/permissions.

BMJ Case Report Fellows may re-use this article for personal use and teaching without any further permission.

Become a Fellow of BMJ Case Reports today and you can:

- Submit as many cases as you like

- Enjoy fast sympathetic peer review and rapid publication of accepted articles

- Access all the published articles

- Re-use any of the published material for personal use and teaching without further permission

For information on Institutional Fellowships contact consortiasales@bmjgroup.com

Visit casereports.bmj.com for more articles like this and to become a Fellow 